\title{
A COMPARATIVE STUDY OF SEVERITY OF DEPRESSION AMONG CAREGIVERS OF PATIENTS SUFFERING FROM DEMENTIA AND CANCER
}

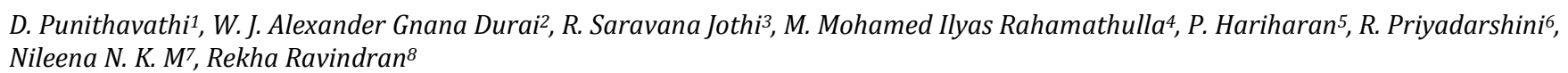

1Junior Resident, Department of Psychiatry, Stanley Medical College, Chennai.
2Professor and HOD, Department of Psychiatry, Stanley Medical College, Chennai.
3Associate Professor, Department of Psychiatry, Stanley Medical College, Chennai.
4Assistant Professor, Department of Psychiatry, Stanley Medical College, Chennai.
5Assistant Professor, Department of Psychiatry, Stanley Medical College, Chennai.
6Junior Resident, Department of Psychiatry, Stanley Medical College, Chennai.
7Junior Resident, Department of Psychiatry, Stanley Medical College, Chennai.
8Junior Resident, Department of Psychiatry, Stanley Medical College, Chennai.

\section{BACKGROUND}

Due to declining global fertility transition and mortality rates, population ageing is a public health challenge. Dementia contributes to a significant proportion of DALY. People with dementia require high level of long-term care and causes burden to the caregivers, both physically and mentally and more prone to depression. The other leading cause of morbidity and mortality in the world is cancer. Because of advancement in palliative care treatment, long-term care is needed for the patients producing definite disturbances in the physical and psychological well-being of the caregivers.

The aim of the study is to compare the prevalence of depressive symptoms among the caregivers of patients with Dementia and Cancer.

\section{MATERIALS AND METHODS}

Caregivers of patients with Dementia and with Cancer, in the age group of 20 - 85 years, were taken into study from a Government hospital in Chennai by consecutive sampling. Socio-demographic details were obtained using semi-structured proforma. Assessment of Depression in caregivers was done using ICD-10 criteria and MADRS.

\section{RESULTS}

The two groups- caregivers of dementia and cancer had similar distribution of gender, marital status, religion, family type, locality and education. According to ICD-10 classification, depression was found high (72.5\%) among caregivers of cancer patients compared to caregivers of dementia patients $(17.5 \%)(p=0.0001)$. Severity of depression was also more in caregivers of cancer patients than the caregivers of dementia patients $(2.5 \%)$.

\section{CONCLUSION}

Depression was found to be four times higher among cancer caregivers than dementia caregivers. Depression has negative effects on quality of life of the caregivers and also the patient.

\section{KEYWORDS}

Caregivers, Dementia, Cancer.

HOW TO CITE THIS ARTICLE: Punithavathi D, Durai WJAG, Jothi RS, et al. A comparative study of severity of depression among caregivers of patients suffering from dementia and cancer. J. Evolution Med. Dent. Sci. 2017;6(77):5493-5497, DOI: 10.14260/Jemds/2017/1192

\begin{abstract}
BACKGROUND
Due to the direct consequence of declining ongoing global fertility transition and declining mortality at older ages, population ageing is an upcoming public health challenge. ${ }^{1}$ Older people, especially who are in eighties and nineties have more prevalence of neuropsychiatric disorders. Dementia is a disease which is more common among older people and contributes to a significant proportion of Years Lived with
\end{abstract}

Financial or Other, Competing Interest: None.

Submission 24-06-2017, Peer Review 12-09-2017,

Acceptance 19-09-2017, Published 25-09-2017.

Corresponding Author:

W. J. Alexander Gnana Durai,

Professor and HOD

Department of Psychiatry,

Stanley Medical College, Chennai.

E-mail:drdralex@gmail.com

DOI: $10.14260 /$ jemds $/ 2017 / 1192$

(c) $(i)$
Disability. Dementia is not commonly met in primary care setting, though they may be extensive in the community. People with dementia generally require high level of care, which are usually given by the family members, who are called unpaid family or informal caregivers. Most of the caregivers are women and other family members. For dementia, they have to give long-term care, so it is associated with significant burden to the caregiver.

Caregiving is associated with significant adverse impact on the caregiver's physical and mental health. ${ }^{2}$ Similarly, the other leading causes of morbidity and mortality in the world is cancer with a prevalence of approximately 14 million new cases and 8.2 million cancer related deaths in 2012. The percentage of new cases expected to rise in next two decades is about $70 \%$. Because of advancement in palliative care treatment, which relieves rather than cure symptoms caused by cancer, it poses a burden to caregivers producing definite disturbances in the physical as well as psychological well- 
being and thereby affects the emotional and financial needs of family members and their caregivers. ${ }^{3}$

In advanced stages of cancer, the physical problems concerning the seriousness of illness, duration of hours of caregiving, dependency of patients on caregivers, financial concerns and low social support were causing more distress and decline in the quality of life for caregivers.(4)

Dementia is defined as "A syndrome of intellectual impairment caused by brain dysfunction, usually of chronic or progressive in nature which is acquired, which compromise three of the following domains like language, memory, visuospatial skills, personality and cognition (Executive function abstraction, calculation, judgement). The incidence of dementia in the community is often underestimated due to reasons that caregivers might mistake memory changes as part of normal ageing process and many older adults are likely to have dementia for many years prior to diagnosis.5,6 Due to advancement in healthcare system, shorter hospital stays, greater use of outpatient treatments there is more pressure on families to take on the caregiving role at home. ${ }^{7}$

Most of the caregiving was provided by family members. ${ }^{8}$ The caregivers become motivated to provide care for reasons like a sense of duty, guilt, social pressures and cultural practices. The caregiving roles and responsibilities taken by the caregivers of the families can often be intense and time consuming and therefore can have major impacts on caregiver's health and lifestyle. ${ }^{9,10}$

Research on caregivers suggest that 6 in 10 caregivers are providing care to an elderly family member for more than two years. One fifth of the caregivers provide care for dementia patients for more than five years. The caregiving role and responsibilities change dramatically over time according to the severity of the disease, usually increasing over time.

According to Patterson, the family caregivers dealing with chronic illness or entire family system undergo a continual, cyclical, adjustment-crisis-adaptation process. ${ }^{11}$ Patient's illness will have an impact on many aspects of family life of caregivers, but it is unclear why some family members are more adversely affected by caregiving than others. ${ }^{12}$

It has been noted in several studies that the problems that mainly affect the caregiver range from tiredness, problems at work, problems with unmet needs of the family, feelings of inadequacy and incapacity, sleeping difficulties, depression and anxiety. The closer the relationship of patient, the higher the depression was noticed in both the cancer groups.

The caregivers of both the groups frequently suffer depression, exhibit maladaptive coping strategies and most of the time express concern about the poor quality of life.13,14,15 They suffer more physical and psychological symptoms and use more frequent prescription medications and healthcare services than general population. ${ }^{16}$

\section{Aim of the Study}

To compare the prevalence of depressive symptoms among the caregivers of patients suffering from Dementia and Cancer.

\section{MATERIALS AND METHODS}

This study is a hospital-based descriptive and comparative study. The study population comprised of 40 caregivers each, of patients with dementia and cancer attending the Outpatient Psychiatry department, Neuromedicine department and Radiotherapy department at Government Stanley Hospital, Chennai, for a period of 6 months after obtaining Institutional Ethical committee clearance. A convenient sample size was taken for this study.

\section{Inclusion Criteria}

- Caregivers of patients satisfying ICD-10 criteria for Dementia and Caregivers of patients diagnosed to have Cancer.

- Participants willing to provide informed consent for the interview and assessment.

- $\quad$ Patients willing to allow Caregivers to be assessed.

- Caregivers aged 20 - 85 years were taken.

\section{Exclusion Criteria}

- Those patients and caregivers who did not give their consent.

- Refusal to allow spouse to be evaluated.

- Caregivers with a history of substance abuse and with a history of suicide attempt/ attempts or previous psychiatric symptoms and interventions.

- $\quad$ Caregivers with a family history of psychiatric illness.

\section{MATERIALS FOR THE ASSESSMENT}

1. Socio-demographic proforma designed for this study.

2. ICD-10 diagnostic criteria checklist for depression.

3. Montgomery-Asberg Depression Rating Scale.

\section{Symptom Checklist Based on ICD-10 Research Diagnostic Criteria $^{17}$}

In typical depressive episodes of all three varieties described below (mild (F32.0), moderate (F32.1) and severe (F32.2 and F32.3)), the individual usually suffers from depressed mood, loss of interest and enjoyment and reduced energy leading to increased fatiguability and diminished activity. Marked tiredness after only slight effort is common. Other common symptoms are: (a) Reduced concentration and attention; (b) Reduced self-esteem and self-confidence; (c) Ideas of guilt and unworthiness (even in a mild type of episode); (d) Bleak and pessimistic views of the future; (e) Ideas or acts of selfharm or suicide; (f) Disturbed sleep; (g) Diminished appetite.

\section{Montgomery-Asberg Depression Rating Scale ${ }^{18}$}

It is a psychological questionnaire used by physicians and other trained professionals to assess the severity of depression among patients who were already diagnosed with depression. It was developed in 1979. The score ranges from 0 to 50 . It includes 10 items. The score from 0 to 6 indicates no depression, the score 7 to 29 indicates mild depression, the score 30 to 34 indicates moderate depression and the score 35 to 60 indicates severe depression. It takes 20 minutes to administer. The correlation for the MADRS was 0.71, slightly higher than for Hamilton Rating scale for Depression (0.65). The inter-rater reliability ranged from 0.89 to 0.97 .

Statistical analysis was done using computerised software (SPSS-20). Descriptive statistics like frequencies, percentages, means and standard deviations were computed. Parametric and non-parametric analyses were used appropriately for comparison between two groups. Chi-square test was used to 
find the difference in severity of depression between the two groups.

\section{RESULTS}

Majority of the caregivers were females for dementia (87.5\%) and cancer patients (95\%). A very few male caregivers were found in both the groups. Chi-square test showed no association between caregiver gender and patient's diagnosis $(\mathrm{p}=0.429)$.

$45 \%$ of the dementia caregivers and $55 \%$ of cancer caregivers belonged to 41 - 60 yrs. age group. Chi-square test showed an association between age of the caregiver and patient's diagnosis $(\mathrm{p}=0.022)$.

$90 \%$ of the dementia caregivers and $82.5 \%$ of the cancer caregivers were married and followed Hinduism. The study revealed $73.8 \%$ of the caregivers lived in a nuclear family, whereas $26.2 \%$ had a joint family. Higher proportion (61.3\%) of the caregivers were from urban area when compared to rural area (38.8).

\begin{tabular}{|c|c|c|c|c|c|c|}
\hline Category & $\begin{array}{c}\text { Dementia } \\
(n=40)\end{array}$ & $\begin{array}{l}\text { Cancer } \\
(n=40)\end{array}$ & $\begin{array}{c}\text { Total } \\
(\mathrm{n}=\mathbf{8 0})\end{array}$ & $\begin{array}{l}\text { Chi- } \\
\text { Square } \\
\text { Value }\end{array}$ & df & $\begin{array}{c}P- \\
\text { value }\end{array}$ \\
\hline \multicolumn{7}{|c|}{ Gender } \\
\hline Male & $\begin{array}{c}5 \\
(12.5 \%)\end{array}$ & $\begin{array}{c}2 \\
(5.0 \%)\end{array}$ & $\begin{array}{c}7 \\
(8.8 \%)\end{array}$ & \multirow{2}{*}{1.409} & \multirow{2}{*}{1} & \multirow{2}{*}{0.429} \\
\hline Female & $\begin{array}{c}35 \\
(87.5 \%) \\
\end{array}$ & $\begin{array}{c}38 \\
(95.0 \%) \\
\end{array}$ & \begin{tabular}{|c|}
73 \\
$(91.3 \%)$ \\
\end{tabular} & & & \\
\hline \multicolumn{7}{|c|}{ Age of the Caregiver } \\
\hline $\begin{array}{c}\leq 40 \\
\text { Yrs. }\end{array}$ & $\begin{array}{c}8 \\
(20.0 \%) \\
\end{array}$ & $\begin{array}{c}14 \\
(35.0 \%) \\
\end{array}$ & \begin{tabular}{|c|}
22 \\
$(27.5 \%)$ \\
\end{tabular} & \multirow{3}{*}{7.59} & \multirow{3}{*}{2} & \multirow{3}{*}{0.022} \\
\hline $\begin{array}{l}41-60 \\
\text { Yrs. }\end{array}$ & $\begin{array}{c}18 \\
(45.0 \%) \\
\end{array}$ & $22(55.0 \%)$ & $\begin{array}{c}40 \\
(50.0 \%) \\
\end{array}$ & & & \\
\hline $\begin{array}{l}\text { Above } \\
60 \text { Yrs. }\end{array}$ & $\begin{array}{c}14 \\
(35.0 \%) \\
\end{array}$ & \begin{tabular}{|c|}
4 \\
$(10.0 \%)$ \\
\end{tabular} & \begin{tabular}{|c|}
18 \\
$(22.5 \%)$ \\
\end{tabular} & & & \\
\hline \multicolumn{7}{|c|}{ Marital Status of Caregivers } \\
\hline $\begin{array}{c}\text { Un- } \\
\text { married }\end{array}$ & $\begin{array}{c}0 \\
(0.0 \%)\end{array}$ & $\begin{array}{c}4 \\
(10.0 \%)\end{array}$ & \begin{tabular}{|c|}
4 \\
$(5.0 \%)$ \\
\end{tabular} & \multirow{4}{*}{6.33} & \multirow{4}{*}{3} & \multirow{4}{*}{0.09} \\
\hline Married & $\begin{array}{c}36 \\
(90.0 \%)\end{array}$ & $\begin{array}{c}33 \\
(82.5 \%)\end{array}$ & $\begin{array}{c}69 \\
(86.3 \%)\end{array}$ & & & \\
\hline Divorced & $\begin{array}{c}2 \\
(5.0 \%) \\
\end{array}$ & $\begin{array}{c}0 \\
(0.0 \%) \\
\end{array}$ & $\begin{array}{c}2 \\
(2.5 \%) \\
\end{array}$ & & & \\
\hline Widowed & $\begin{array}{c}2 \\
(5.0 \%) \\
\end{array}$ & $\begin{array}{c}3 \\
(7.5 \%) \\
\end{array}$ & \begin{tabular}{|c|}
5 \\
$(6.3 \%)$ \\
\end{tabular} & & & \\
\hline \multicolumn{7}{|c|}{ Religion of Caregiver } \\
\hline Hindu & $\begin{array}{c}30 \\
(75.0 \%) \\
\end{array}$ & $\begin{array}{c}32 \\
(80.0 \%) \\
\end{array}$ & \begin{tabular}{|c|}
62 \\
$(77.5 \%)$ \\
\end{tabular} & \multirow{3}{*}{0.465} & \multirow{3}{*}{2} & \multirow{3}{*}{0.793} \\
\hline Muslim & $\begin{array}{c}4 \\
(10.0 \%) \\
\end{array}$ & $\begin{array}{c}4 \\
(10.0 \%) \\
\end{array}$ & $\begin{array}{c}8 \\
(10.0 \%) \\
\end{array}$ & & & \\
\hline Christian & $\begin{array}{c}6 \\
(15.0 \%) \\
\end{array}$ & $\begin{array}{c}4 \\
(10.0 \%) \\
\end{array}$ & $\begin{array}{c}10 \\
(12.5 \%) \\
\end{array}$ & & & \\
\hline \multicolumn{7}{|c|}{ Type of Family } \\
\hline $\begin{array}{c}\text { Nuclear } \\
\text { Family }\end{array}$ & $\begin{array}{c}31 \\
(77.5 \%)\end{array}$ & $\begin{array}{c}28 \\
(70.0 \%)\end{array}$ & $\begin{array}{c}59 \\
(73.8 \%)\end{array}$ & \multirow{2}{*}{1.95} & \multirow{2}{*}{2} & \multirow[b]{2}{*}{0.377} \\
\hline $\begin{array}{c}\text { Joint } \\
\text { Family }\end{array}$ & $\begin{array}{c}9 \\
(22.5 \%)\end{array}$ & $\begin{array}{c}12 \\
(30.0 \%)\end{array}$ & $\begin{array}{c}20 \\
(26.2 \%) \\
\end{array}$ & & & \\
\hline \multicolumn{7}{|c|}{ Locality } \\
\hline Rural & $\begin{array}{c}15 \\
(37.5 \%) \\
\end{array}$ & $\begin{array}{c}16 \\
(40.0 \%) \\
\end{array}$ & \begin{tabular}{|c|}
31 \\
$(38.8 \%)$ \\
\end{tabular} & \multirow{2}{*}{0.053} & \multirow{2}{*}{1} & \multirow{2}{*}{0.818} \\
\hline Urban & $\begin{array}{c}25 \\
(62.5 \%) \\
\end{array}$ & $\begin{array}{c}24 \\
(60.0 \%) \\
\end{array}$ & \begin{tabular}{|c|}
49 \\
$(61.3)$ \\
\end{tabular} & & & \\
\hline \multicolumn{7}{|c|}{$\begin{array}{c}\text { Table 1. Socio-Demographic Characteristics of the } \\
\text { Caregivers of Patients Diagnosed with Dementia and } \\
\text { Cancer }\end{array}$} \\
\hline
\end{tabular}

\begin{tabular}{|c|c|c|c|c|c|c|}
\hline Category & $\begin{array}{c}\text { Dementia } \\
(n=40)\end{array}$ & $\begin{array}{l}\text { Cancer } \\
(n=40)\end{array}$ & $\begin{array}{c}\text { Total } \\
(n=80)\end{array}$ & \begin{tabular}{|c|} 
Chi- \\
Square \\
Value \\
\end{tabular} & df & $\begin{array}{c}\text { P- } \\
\text { value }\end{array}$ \\
\hline \multicolumn{7}{|c|}{ Educational Status of Caregivers } \\
\hline Illiterate & $\begin{array}{c}13 \\
(32.5 \%)\end{array}$ & $\begin{array}{c}18 \\
(45.0 \%)\end{array}$ & $\begin{array}{c}31 \\
(38.8 \%)\end{array}$ & \multirow{4}{*}{1.98} & \multirow{4}{*}{3} & \multirow{4}{*}{0.576} \\
\hline $\begin{array}{l}\text { Middle } \\
\text { School }\end{array}$ & $\begin{array}{c}16 \\
(40.0 \%)\end{array}$ & $\begin{array}{c}15 \\
(37.5 \%)\end{array}$ & $\begin{array}{c}31 \\
(38.8 \%)\end{array}$ & & & \\
\hline $\begin{array}{l}\text { High/Hr. } \\
\text { Sec School }\end{array}$ & $\begin{array}{c}9 \\
(22.5 \%)\end{array}$ & $\begin{array}{c}5 \\
(12.5 \%)\end{array}$ & $\begin{array}{c}14 \\
(17.5 \%)\end{array}$ & & & \\
\hline Graduates & $\begin{array}{c}2 \\
(5.0 \%)\end{array}$ & $\begin{array}{c}2 \\
(5.0 \%)\end{array}$ & $\begin{array}{c}4 \\
(5.0 \%) \\
\end{array}$ & & & \\
\hline \multicolumn{7}{|c|}{ Occupation of Caregiver } \\
\hline $\begin{array}{c}\text { Un- } \\
\text { employed }\end{array}$ & $\begin{array}{c}26 \\
(65.0 \%)\end{array}$ & $\begin{array}{c}15 \\
(37.5 \%)\end{array}$ & $\begin{array}{c}41 \\
(51.3)\end{array}$ & \multirow{2}{*}{6.05} & \multirow{2}{*}{1} & \multirow{2}{*}{0.014} \\
\hline Employed & $\begin{array}{c}14 \\
(35.0 \%)\end{array}$ & $\begin{array}{c}25 \\
(62.5 \%)\end{array}$ & $\begin{array}{c}39 \\
(48.8 \%)\end{array}$ & & & \\
\hline \multicolumn{7}{|l|}{ Income } \\
\hline $\begin{array}{c}\text { Below Rs. } \\
3000 /-\end{array}$ & $\begin{array}{c}17 \\
(42.5 \%)\end{array}$ & $\begin{array}{c}15 \\
(35.5 \%)\end{array}$ & $\begin{array}{c}32 \\
(40.0 \%)\end{array}$ & \multirow{4}{*}{0.224} & \multirow{4}{*}{3} & \multirow{4}{*}{0.974} \\
\hline $\begin{array}{c}\text { Rs. } 3000 \text { - } \\
4999\end{array}$ & $\begin{array}{c}12 \\
(30.0 \%)\end{array}$ & $\begin{array}{c}13 \\
(32.5 \%)\end{array}$ & $\begin{array}{c}25 \\
(31.3 \%)\end{array}$ & & & \\
\hline $\begin{array}{l}\text { Rs. } 5000 \text { - } \\
9999\end{array}$ & $\begin{array}{c}8 \\
(20.0 \%)\end{array}$ & $\begin{array}{c}9 \\
(22.5 \%)\end{array}$ & $\begin{array}{c}17 \\
(21.3 \%)\end{array}$ & & & \\
\hline $\begin{array}{l}\text { Rs. } 10,000 \\
\text { and Above }\end{array}$ & $\begin{array}{c}3 \\
(7.5 \%)\end{array}$ & $\begin{array}{c}3 \\
(7.5 \%)\end{array}$ & $\begin{array}{c}6 \\
(7.5 \%)\end{array}$ & & & \\
\hline \multicolumn{7}{|c|}{ Relationship to the Patients } \\
\hline Siblings & $\begin{array}{c}2 \\
(5.0 \%)\end{array}$ & $\begin{array}{c}1 \\
(2.5 \%)\end{array}$ & $\begin{array}{c}3 \\
(3.8 \%) \\
\end{array}$ & \multirow{5}{*}{8.8} & \multirow{5}{*}{4} & \multirow{5}{*}{0.065} \\
\hline Spouse & $\begin{array}{c}21 \\
(52.5 \%)\end{array}$ & $\begin{array}{c}28 \\
(70.0 \%) \\
\end{array}$ & $\begin{array}{c}49 \\
(61.3 \%) \\
\end{array}$ & & & \\
\hline $\begin{array}{l}\text { Daughter/ } \\
\text { Son }\end{array}$ & $\begin{array}{c}8 \\
(20.0 \%)\end{array}$ & $\begin{array}{c}6 \\
(15.0 \%)\end{array}$ & $\begin{array}{c}14 \\
(17.5 \%)\end{array}$ & & & \\
\hline $\begin{array}{c}\text { Daughter/ } \\
\text { Son-in-Law }\end{array}$ & $\begin{array}{c}8 \\
(20.0 \%)\end{array}$ & $\begin{array}{c}1 \\
(2.5 \%)\end{array}$ & $\begin{array}{c}9 \\
(11.3)\end{array}$ & & & \\
\hline Others & $\begin{array}{c}1 \\
(2.5 \%)\end{array}$ & $\begin{array}{c}4 \\
(10.0 \%)\end{array}$ & $\begin{array}{c}5 \\
(6.3 \%)\end{array}$ & & & \\
\hline \multicolumn{7}{|c|}{ Participation of Other Caregivers } \\
\hline No & $\begin{array}{c}27 \\
(67.5 \%)\end{array}$ & $\begin{array}{c}36 \\
(90.0 \%)\end{array}$ & $\begin{array}{c}63 \\
(78.8 \%)\end{array}$ & \multirow{2}{*}{6.05} & \multirow{2}{*}{1} & \multirow{2}{*}{0.27} \\
\hline Yes & $\begin{array}{c}13 \\
(32.5 \%)\end{array}$ & $\begin{array}{c}4 \\
(10.0 \%)\end{array}$ & $\begin{array}{c}17 \\
(21.3 \%)\end{array}$ & & & \\
\hline \multicolumn{7}{|c|}{ Chronic Illness } \\
\hline No & $\begin{array}{c}26 \\
(65.0 \%)\end{array}$ & $\begin{array}{c}27 \\
(67.5 \%)\end{array}$ & $\begin{array}{c}53 \\
(66.3 \%)\end{array}$ & \multirow{2}{*}{0.56} & \multirow{2}{*}{10} & \multirow{2}{*}{0.813} \\
\hline Yes & $\begin{array}{c}14 \\
(35.0 \%)\end{array}$ & $\begin{array}{c}13 \\
(32.5 \%)\end{array}$ & $\begin{array}{c}27 \\
(33.8 \%)\end{array}$ & & & \\
\hline & Socio-Ec & omic Var & riables of & & & \\
\hline
\end{tabular}

Illiterates were high $(38.8 \%)$ among cancer caregivers than Dementia caregivers $(32.5 \%)$ and $22.5 \%$ of dementia caregivers had completed secondary education as compared to cancer caregivers (12.5\%). Nearly, 17 (42.5\%) of Dementia caregiver's and 15 (35.5\%) of cancer caregiver's monthly income was below Rs. 3000/-. Among the caregivers to dementia patients $70.0 \%$ were spouses and $17.5 \%$ were son/daughters, whereas $70.0 \%$ were spouses and $15.0 \%$ were daughter/sons among cancer caregivers. But there was no significant difference with respect to marital status, 
religion, type of family, education, locality, monthly income and relationship of the caregiver to the patient.

The proportion of duration of caregiving of less than one year was $52.5 \%$ and $60.0 \%$ among caregiver of dementia and cancer patients respectively. Care given for 1 - 5 years was $40 \%$ and $35 \%$ respectively for each group. Care was given for more than 5 years by $7.5 \%$ and $5 \%$ of caregivers of dementia and cancer patients respectively. The difference between duration of caregiving in dementia and cancer caregivers was not statistically significant $(\mathrm{p}=0.766)$. Participation of other caregivers to Dementia patient was $32.5 \%$ and only $10.0 \%$ for cancer patients and this was also statistically not significant; $65 \%$ of dementia caregivers and $67.5 \%$ of cancer caregivers were themselves suffering from some form of chronic illness and the difference was not significant.

\begin{tabular}{|c|c|c|c|c|c|c|}
\hline Category & $\begin{array}{c}\text { Dementia } \\
(n=40)\end{array}$ & $\begin{array}{l}\text { Cancer } \\
(n=40)\end{array}$ & $\begin{array}{c}\text { Total } \\
(n=80)\end{array}$ & \begin{tabular}{|c|} 
Chi- \\
Square \\
Value
\end{tabular} & df & $\begin{array}{c}\text { P- } \\
\text { value }\end{array}$ \\
\hline \multicolumn{7}{|c|}{ Depression in Caregiver } \\
\hline No & $\begin{array}{c}33 \\
(82.5 \%)\end{array}$ & $\begin{array}{c}11 \\
(27.5 \%)\end{array}$ & \begin{tabular}{|c|}
44 \\
$(55.0 \%)$
\end{tabular} & \multirow{2}{*}{24.44} & \multirow{2}{*}{1} & \multirow{2}{*}{0.0001} \\
\hline Yes & $\begin{array}{c}7 \\
(17.5 \%)\end{array}$ & $\begin{array}{c}29 \\
(72.5 \%)\end{array}$ & $\begin{array}{c}36 \\
(45.0 \%)\end{array}$ & & & \\
\hline \multicolumn{7}{|c|}{ Severity of Depression } \\
\hline $\begin{array}{l}\text { Little/No } \\
\text { Depression }\end{array}$ & $\begin{array}{c}32 \\
(80.0 \%)\end{array}$ & $\begin{array}{c}11 \\
(27.5 \%)\end{array}$ & \begin{tabular}{|c|}
43 \\
$(53.8 \%)$
\end{tabular} & \multirow{4}{*}{24.2} & \multirow{4}{*}{3} & \multirow{4}{*}{0.000} \\
\hline Mild & $\begin{array}{c}6 \\
(15.0 \%)\end{array}$ & $\begin{array}{c}12 \\
(30.0 \%)\end{array}$ & $\begin{array}{c}18 \\
(22.5 \%)\end{array}$ & & & \\
\hline Moderate & $\begin{array}{c}1 \\
(2.5 \%)\end{array}$ & $\begin{array}{c}5 \\
(12.5 \%)\end{array}$ & $\begin{array}{c}6 \\
(7.5 \%)\end{array}$ & & & \\
\hline Severe & $\begin{array}{c}1 \\
(2.5 \%) \\
\end{array}$ & $\begin{array}{c}12 \\
(30.0 \%) \\
\end{array}$ & $\begin{array}{c}13 \\
(16.3 \%)\end{array}$ & & & \\
\hline \multicolumn{7}{|c|}{ ICD-10 Classification } \\
\hline $\begin{array}{c}\text { No } \\
\text { Depression }\end{array}$ & $\begin{array}{c}33 \\
(82.5 \%)\end{array}$ & $\begin{array}{c}11 \\
(27.5 \%)\end{array}$ & $\begin{array}{c}44 \\
(55.0 \%)\end{array}$ & \multirow{2}{*}{24.44} & \multirow[b]{2}{*}{1} & \multirow{2}{*}{0.0001} \\
\hline Depression & $\begin{array}{c}7 \\
(17.5 \%)\end{array}$ & $\begin{array}{c}29 \\
(72.5 \%)\end{array}$ & $\begin{array}{c}36 \\
(45.5 \%)\end{array}$ & & & \\
\hline $\begin{array}{l}\text { Table } \\
\text { Caregi }\end{array}$ & . & $\begin{array}{r}\text { f Depres } \\
\text { Cants Diagr } \\
\text { Canc }\end{array}$ &. & & & and \\
\hline
\end{tabular}

Depression was found to be high (72.5\%) among caregivers of cancer patient when compared to caregivers of dementia patients $(17.5 \%)$ and was statistically significant $(p=0.0001) ; 30.0 \%$ of the caregivers of cancer patients had severe depression compared to $2.5 \%$ of dementia caregivers with a statistical significance of $\mathrm{p}=0.0001$. Both mild and moderate depression were also comparatively high in cancer caregivers.

The MADRS score of caregivers of cancer patients was significantly higher $(M=20.38, S D=16.23)$ than that of caregivers of dementia patients $(M=5.28, S D=7.58), t(55.2)$ $=5.33, \mathrm{p}=0.0001$.

\section{DISCUSSION}

The two groups- caregivers of dementia and cancer had generally similar distribution of gender, marital status, religion, family type, locality and education. All of these variables were found to be statistically not significant between the two groups, and so the groups were comparable.

Most of the dementia caregivers were unemployed when compared to cancer caregivers, which was statistically significant. In these two groups, the income of the caregivers, relationship to patient, participation of other family members in caregiving, chronic illness among caregivers were found to be statistically not significant, because it was approximately same in both the groups and so the groups were comparable. These results were similar to studies done by Zyada et al and Mohammed Ali Heidari et al. ${ }^{19,20}$

Depression was high among the 40 - 60 yrs. aged caregivers of the two groups and a statistically significant association was present between caregiver's age and depression. There were more female caregivers than male caregivers, but it was not statistically significant. The depression was more among the employed caregivers, but the association was not statistically significant. Likewise, the caregiver's depression was higher in both group's caregivers who were not having other family member's support, but the association was not statistically significant.

The dementia caregiver's depression findings were similar to study Lambert et al $(17 \%) .{ }^{21,22}$ The cancer caregiver's depression results were similar to the results in studies like Siew Tzuh Tang et al (75.9\%) and in Rhee YS et al $(67 \%))^{23,24}$

In dementia caregivers $8.0 \%$ had little or no depression, $15 \%$ had mild depression, $2.5 \%$ had moderate depression and $2.5 \%$ had severe depression. In cancer caregivers it was $27.5 \%, 30.0 \%, 12.5 \%$ and $30.0 \%$ for little or no depression, mild depression, moderate depression and severe depression respectively. The difference between the two groups was statistically significant. In Mohammed Ali Heidari Gorji and Zinnatossadat Bouzar study, Beach SR and Schulz R study, ${ }^{25}$ there were more mild and moderate depression among cancer caregivers. But in our study, equal prevalence of mild and severe depression among cancer caregivers was noted.

The association between age of the caregiver and depression was compared among these two groups and was found to be statistically significant $(\mathrm{p}=0.014)$. Because mean age of developing depression among these two groups were having a difference of 8 to 9 years.

\section{Limitation}

The caregiver's sample was taken only from hospital-based patients, so the sample may be an over representation of caregivers than from the general population. Individual differences in caregivers like their personality, attitudes, cultural beliefs and ethnicity were not taken into account. The sample size was small and not community based. The preexposure coping strategies and other domains of caregivers were not taken into account.

\section{CONCLUSION}

Depression was found to be four times higher among cancer caregivers than dementia caregivers and so was the severity. Depression was higher among caregivers of 40 - 60 years. As the age increased above 60 years, the depression tends to increase in dementia caregivers. The results of our study give information about various factors and domains of caregiving role and help the caregivers to understand the challenges when caring for the patients and in turn help health care professionals to meet the needs of the caregiver in strain. Depression has negative effect on quality of life of caregivers and also patients. So, assistance, psycho education and early intervention from health care professionals is the key to 


\section{Jemds.com}

improve the quality of life of caregivers and hence the patient's quality of life.

\section{REFERENCES}

[1] World Health Organization: world health statistics 2014: p. 42. www.who.int/gho/publications/world_ health_statistics/2014/en.

[2] World Health Organization. The global burden of disease: 2004 Update 2008: p. 40. www.who.int/healthinfo/global_burden_disease/200 4_report_update/en/index.html

[3] Prince M. Dementia in developing countries. A preliminary consensus statement from the 10/66 Dementia Research Group. International Journal of Geriatric Psychiatry 2000;15(1):14-20.

[4] Le Navenec CL, Vonhof T. One day at a time: how families manage the experience of dementia. Westport, CT, Auburn house, USA: Greenwood Publishing Group Inc., 1996:25-44.

[5] Stenberg U, Ruland CM, Miaskowski C. Review of the literature on the effects of caring for a patient with cancer. Psychooncology 2010;19(10):1013-25.

[6] Kennet J, Burgio L, Schulz R. Interventions for in-home caregivers: a review of research 1990 to present. In: Schulz R. edr. Handbook on dementia caregiving. Evidence-based interverventions for family caregivers. New York: Springer 2000:61-126.

[7] Cranswick K. Burnout: a study of levels of burnout and factors responsible for burnt out in rehabilitation workers. Journal of Rehabilitation Administration 1997;21(2):119-34.

[8] Cantor MH. Family and community: changing roles in an aging society. Gerontologist 1991;31(3):337-46.

[9] Lieberman MA, Fisher L. The impact of chronic illness on the health and well-being of family members. The Gerontologist 1995;35(1):94-102.

[10] Schulz R, O'Brien AT, Bookwala J, et al. Psyhiatric and physical morbidity effects of dementia caregiving: prevalence, correlates and causes. Gerontologist 1995;35(6):771-91.

[11] Patterson TL, Semple SJ, Shaw WS, et al. The cultural context of caregiving: a comparison of Alzheimer's caregivers in Shanghai, China and San Diego, California. Psychological Medicine 1998;28(5):107184.

[12] Georges J, Jansen S, Jackson J, et al. Alzheimer's disease in real life-the dementia carer's survey. Int J Geriatr Psychiatry 2008;23(5):546-51.

\section{Original Research Article}

[13] Serrano-Aguilar PG, Lopez-Bastida J, Yanes-Lopez V. Impact on health related quality of life and perceived burden of informal caregivers of individuals with Alzheimer's disease. Neuroepidemiology 2006;27(3):136-42.

[14] Papatavrou E, Kalokerinou A, Papacostas SS, et al. Caring for relative with dementia: family caregiver burden. Journal of Advanced Nursing 2007;58(5):44657.

[15] Molyneux GJ, McCarthy GM, McEniff S, et al. Prevalence and predictors of caregiver burden and depression in carers of patients referred to an old age psychiatric service. Int Psychogeriatr 2008;20(6):1193-202.

[16] Brodaty H, Green A. Defining the role of caregiver in Alzheimer's disease treatment. Drugs and Ageing 2002;19(12):891-8.

[17] World Health Organization. The ICD-10 Classification of mental and behavioural disorders. Clinical descriptions and diagnostic guidelines. Geneva: WHO. 1992:99-101.

[18] Montgomery SA, Asberg M. A new depression scale designed to be sensitive to change. Br J Psychiatry 1979;134(4):382-9.

[19] Zyada F, Shetha M, El Degwi H, et al. Anxiety, depression and strain among caregivers of terminally ill patients. Egyptian Journal of Psychiatry 2013;34(2):77-84.

[20] Gorji HMA, Bouzar Z, Haghshenas M, et al. Quality of life and depression in caregivers of patients with breast cancer. BMC Res Notes 2012:5:310.

[21] Girgis A, Lambert S, Johnson C, et al. Physical, psychosocial, relationship and economic burden of caring for people with cancer: a review. J Oncol Oncology Pract 2013;9(4):197-202.

[22] Lambert SD, Yoon H, Ellis KR, et al. Measuring appraisal during advanced cancer: psychometric testing of the appraisal of caregiving scale. Patient Education and Counselling 2015;98(5):633-9.

[23] Tang ST, Li CY, Liao YC. Factors associated with depressive distress among Taiwanese family caregivers of cancer patients at the end of life. Palliative Medicine 2007;21(3):249-57.

[24] Rhee YS, Yun YH, Park S, et al. Depression in family caregivers of cancer patients: the feeling of burden as a predictor of depression. J Clin Oncology 2008;26(36):5890-5.

[25] Beach SR, Schulz R, Williamson GM, et al. Risk factors for potentially harmful informal caregiver behaviour. J Am Geriatr Soc 2005;53(2):255-61. 